\title{
Sustainable development goals as a tool for strategic planning in communities: a bibliometric analysis of research
}

\author{
Yuriy Petrushenko, Vadym Aleksandrov, Anna Vorontsova, and Oksana Ponomarenko* \\ Department of International Economic Relations, Sumy State University, 2, Rimskogo- Korsakova \\ street, Sumy, 40007, Ukraine
}

\begin{abstract}
Nowadays, the balanced development of any territorial unit should be based on the concept of sustainable development. As a result of its significant expansion, the goals of sustainable development began to be used at the level of strategic and operational documents, which in the context of decentralization is reflected at the level of individual territorial communities. This article is devoted to bibliometric analysis of the scientific papers from the Web of Science and Scopus, which deals with the topic of sustainable development in local communities as elements of strategic planning. To do this, we used the VOS viewer, Scopus, and Web of Science tools, which made it possible to identify major trends (for example, dynamics by year, country, authors, subject area, etc.) and clusters that visually present the obtained information. The following key parameters were also selected for the analysis: published for 1987-2019 years; the language of the paper - English; papers which contain keywords - sustainable development, local communities, and strategic planning. The results indicate a growing role of the chosen topic, which prevails in environmental and social sciences. The bibliometric analysis revealed 8 clusters (Scopus database) and 11 clusters (Vos database) with the central term "sustainable development". The term "local communities" is also one of the key ones in the analyzed research, which is confirmed by the number and strength of links. The analyzed trends show that sustainable development is increasingly considered at the local level of territorial communities in the context of their planning and development.
\end{abstract}

\section{Introduction}

In modern realities the basic ideas of the concept of "sustainable development" are becoming an integral part of most government programs and strategies, which is reflected in all areas of the national economy. Traditionally, they take into account and keep a balance of the economic, environmental, and social components of the country's development through the achievement of the UN-proposed goals and indicators.

At the same time, there is a dynamic in the world, according to which most countries are moving to a model of decentralized management, which makes it possible to make more

* Corresponding author: Ponomarenkoxana@gmail.com 
effective local decisions and independently choose the trajectories of local development. It is in this context that achieving the goals of sustainable development can be considered a tool for strategic planning in local communities. This issue is of considerable scientific interest, which determines the high relevance of the chosen topic.

The aim of this paper is to conduct a bibliometric analysis of sustainable development tools in local communities and to highlight the main scientific clusters and trends of investigating these issues.

\section{Literature review}

The increase in powers (financial, fiscal, authoritative, etc.) at the local level as a result of decentralization processes has been the subject of numerous studies [1-4], which confirm the connection with the country's economic, social and innovative development. At the same time, the focus of most scientific works is on empirical confirmation of the connection between economic indicators of the country's development and the ecological and social component, in particular in works [5-8].

Some researchers have devoted their work to the study of energy independence of all types of resources and investments in renewable energy as a guarantee of sustainable development [9-17]. The study of forecasting of the country's development strategy based on social progress and macroeconomic stability, lifelong learning, as well as the country's food security and the role of sustainable development have been reflected in numerous scientific papers [18-26]. The growing importance of corporate, social and environmental responsibility of business, which has become an integral part of national strategies for sustainable development, is also in the sphere of scientific interests of modern researchers [27-32].

\section{Results and Discussions}

In the first stage of bibliometric analysis it is necessary to make a sample of data from international scientific databases Scopus and Web of Science (WoS), which will make it possible to qualitatively and quantitatively analyze the number of works on sustainable development at the level of local communities. To do this, we propose to compare the amount of the sorted data, depending on the specifics of the search (Table 1). 
Table 1. Search results in Scopus and WoS databases due to different variations of keywords

\begin{tabular}{|l|c|c|}
\hline \multicolumn{1}{|c|}{ Keywords Combination } & $\begin{array}{c}\text { Number of } \\
\text { articles } \\
\text { (Scopus) }\end{array}$ & $\begin{array}{c}\text { Number of } \\
\text { articles (WoS) }\end{array}$ \\
\hline $\begin{array}{l}\text { Sustainable development AND local } \\
\text { communities }\end{array}$ & 2318 & 1118 \\
\hline $\begin{array}{l}\text { 2. Sustainable development AND local } \\
\text { communities AND planning }\end{array}$ & 963 & 192 \\
\hline $\begin{array}{l}\text { 3. Sustainable development AND local } \\
\text { communities AND strategic planning }\end{array}$ & 70 & 15 \\
\hline
\end{tabular}

As you can see, most of our search is in the first combination, which was chosen as the basis for further research.

Let us analyze the number of works devoted to the study of sustainable development at the level of territorial communities in the international scientific databases Scopus and Web of Science (WoS) in 1987-2019 (Figure 1).

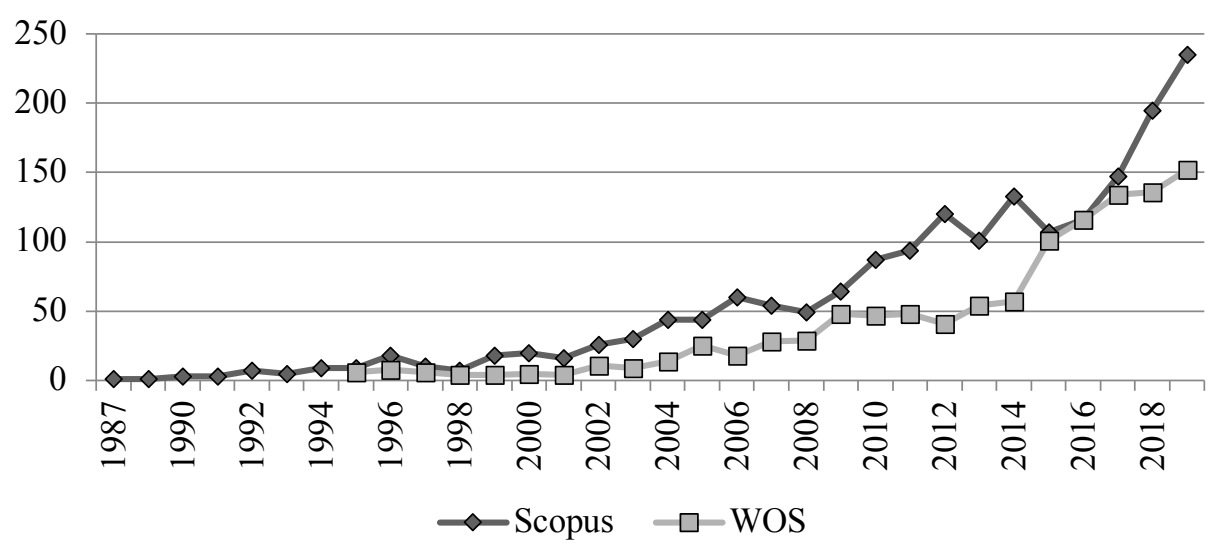

Fig. 1. The number of papers on the sustainable development in local communities in Scopus and WoS database for 1987-2019 years (Developed by the authors using Scopus and WoS Tools)

This topic has been found in scientific papers since 1987 (in the Scopus database), which is associated with the emergence of the very concept of sustainable development. It should be noted that its expansion was preceded by numerous eco-centric theories (for example, ecotype, environmental protection, etc.). It is known that in 1987 the term "sustainable development" was used in the report of the United Nations World Commission on Environment and Development (WCED) "Our Common Future" also known as the Brundtland Report. The landmark year is also 1992, when the UN Agenda on Environment and Development in Rio de Janeiro, Brazil, adopted the action plan Agenda 21.

The number of papers devoted to sustainable development in local communities has been growing in both databases since 2000 (20 papers in Scopus and 5 papers in WoS), which can also be linked to a historic event in the concept of sustainable development - the UN summit adopted the United Nations Millennium Declaration (Resolution 55/2). Rapid growth has also been observed since 2012-2015. It should be noted that in 2015 the current 17 Sustainable Development Goals (SDGs) were adopted by the UN Resolution 70/1/. 
As of 2019 the Scopus database publishes 235 works devoted to sustainable development in local communities, WoS database - 152. The total number of works in the analyzed period is 1833 and 1118 , respectively.

In the context of our research it is interesting to consider the main areas in which sustainable development in local communities is studied. Using Scopus and WoS Tools we obtained the following summary (Table 3 ).

Table 2. The number of papers on the sustainable development in local communities in Scopus database by subject area

\begin{tabular}{|l|c|c|}
\hline \multicolumn{1}{|c|}{ Subject area } & $\begin{array}{c}\text { Number of } \\
\text { papers in Scopus }\end{array}$ & $\begin{array}{c}\text { Number of } \\
\text { papers in WoS }\end{array}$ \\
\hline Environmental Science & 912 & 476 \\
\hline Social Sciences & 739 & 240 \\
\hline Engineering & 346 & 104 \\
\hline Earth and Planetary Sciences & 299 & 92 \\
\hline Energy, Materials Science & 311 & 234 \\
\hline $\begin{array}{l}\text { Agricultural and Biological Sciences, } \\
\text { Chemistry }\end{array}$ & 274 & 248 \\
\hline Business, Management and Accounting & 249 & 279 \\
\hline Economics, Econometrics and Finance & 111 & 13 \\
\hline Computer Science & 92 & 32 \\
\hline Arts and Humanities & 56 & 25 \\
\hline Medicine and oth., Psychology & 92 & 17 \\
\hline Decision Sciences & 36 & 8 \\
\hline Mathematics, Physics and Astronomy & 50 & 40 \\
\hline Multidisciplinary & 13 & 22 \\
\hline
\end{tabular}

Sources: developed by the authors using Scopus and WoS Tools

The obtained data show that most works in this field are concentrated in Environmental Science (912 works in Scopus and 476 works in WoS), Social Sciences (739 works in Scopus and 240 works in WoS), in Engineering (346 works in Scopus) and in Business, Management and Accounting (249 works in Scopus and 279 works in WoS). This emphasizes the importance and applicability of this concept in all areas of the national economy, and especially in the three classical ones - economic, social and environmental.

On the next stage we propose to consider the geography of research on the sustainable development in local communities (Fig. 2). 


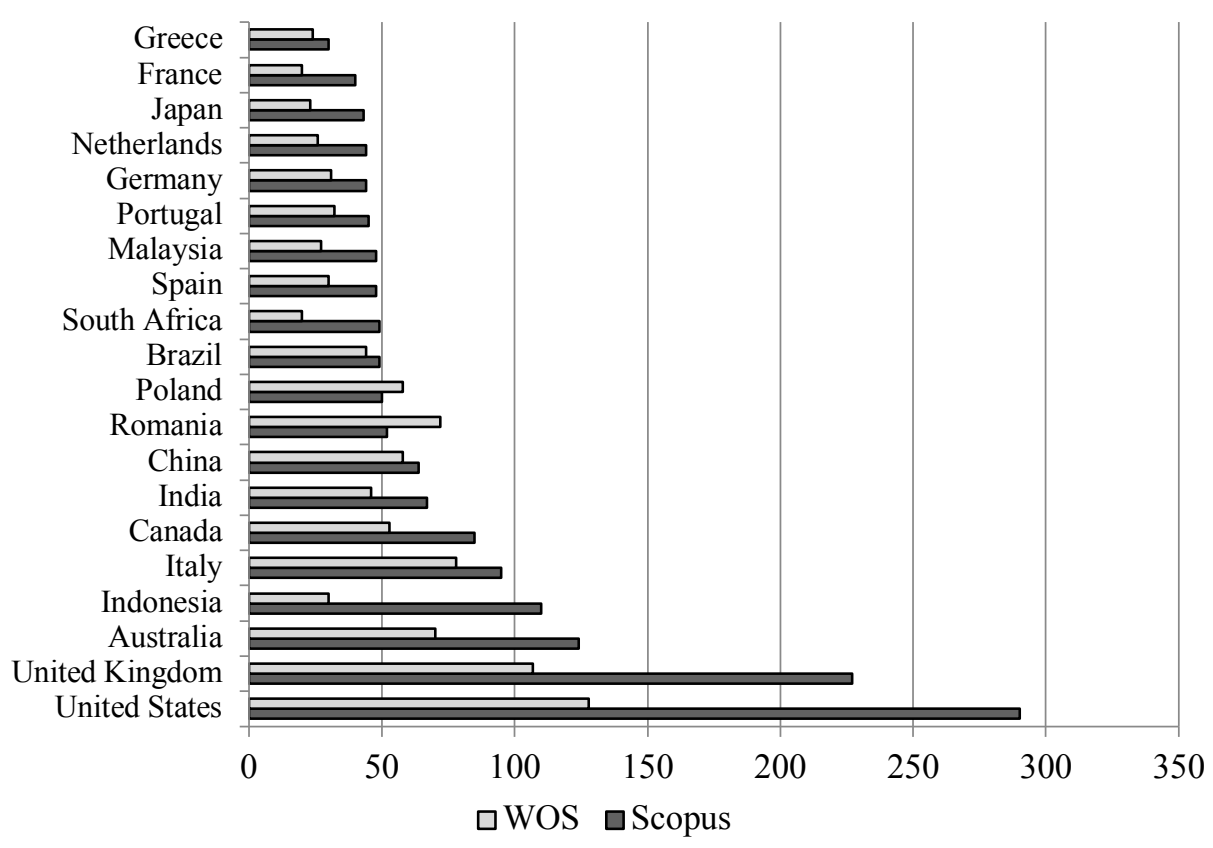

Fig. 2. The number of papers on the sustainable development in local communities in Scopus and WoS database for 1987-2019 years by country (Developed by the authors using Scopus and WoS

$$
\text { Tools) }
$$

According to the geography of distribution, the biggest number of studies are conducted in English-speaking countries - the United States (290 works in Scopus and 128 works in WoS), the United Kingdom (227 works in Scopus and 107 works in WoS) and Australia (124 works in Scopus and 70 works in WoS). It should be noted that the graph shows only the first 20 countries in the list for the clarity of presentation. Therefore, according to our graph, the last places belong to Japan (43 works in Scopus and 23 works in WoS), France ( 40 works in Scopus and 20 works in WoS) and Greece (30 works in Scopus and 24 works in $\mathrm{WoS})$.

We will consider the key authors (top 5) in the field of sustainable development in local communities in Scopus and WoS database (Table 3). 
Table 3. The top 5 contributing authors in the area of sustainable development in local communities (Scopus and WoS Database)

\begin{tabular}{|c|c|c|c|}
\hline \multicolumn{2}{|l|}{ Scopus } & \multicolumn{2}{|l|}{ WoS } \\
\hline Author/Aliation & $\begin{array}{l}\text { Number } \\
\text { of } \\
\text { papers }\end{array}$ & Author/Aliation & $\begin{array}{c}\text { Number } \\
\text { of } \\
\text { papers }\end{array}$ \\
\hline $\begin{array}{l}\text { Awuah-Offei, K. } \\
\text { Missouri University of Science } \\
\text { and Technology, Rolla, United } \\
\text { States }\end{array}$ & 5 & $\begin{array}{l}\text { Veghes, C. } \\
\text { Bucharest University of } \\
\text { Economic Studies } \\
\text { Bucharest, Romania }\end{array}$ & 5 \\
\hline $\begin{array}{l}\text { Booth, C.A. } \\
\text { University of the West of } \\
\text { England, Bristol, United } \\
\text { Kingdom }\end{array}$ & 4 & $\begin{array}{l}\text { Booth, C.A. } \\
\text { University of the West of } \\
\text { England, Bristol, United } \\
\text { Kingdom }\end{array}$ & 4 \\
\hline $\begin{array}{l}\text { Mazilu, M. } \\
\text { University of Craiova, Craiova }\end{array}$ & 4 & $\begin{array}{l}\text { Davies, K. } \\
\text { University of Wolverhampton } \\
\text { Wolverhampton, W Midlands, } \\
\text { England }\end{array}$ & 4 \\
\hline $\begin{array}{l}\text { Nijnik, M. } \\
\text { The James Hutton Institute, } \\
\text { Aberdeen, United Kingdom }\end{array}$ & 4 & $\begin{array}{l}\text { Fullen, Michael A. } \\
\text { University of Wolverhampton } \\
\text { Fac Engn \& Technol } \\
\text { Wolverhampton, England }\end{array}$ & 4 \\
\hline $\begin{array}{l}\text { Que, S. } \\
\text { Chongqing } \quad \text { University, } \\
\text { Chongqing, China }\end{array}$ & 4 & $\begin{array}{l}\text { Munasinghe, Mohan } \\
\text { Munasinghe Inst Dev MIND } 10 \\
\text { De Fonseka P1 } \\
\text { Colombo, Sri Lanka }\end{array}$ & 4 \\
\hline
\end{tabular}

As we see, the total number of works on this topic is small, which emphasizes its inadequate research and the necessity of its further development.

Considering the main funding sponsors of these works (in the selected sample sponsors financed at least five works) we have the following structure (Table 1). Most of the works were funded by the European Commission ( 30 works), the National Natural Science Foundation of China (13 works) and the National Science Foundation (10 works). 
Table 4. Main funding sponsors who support the investigations on the sustainable development in local communities

\begin{tabular}{|c|c|c|}
\hline Funding sponsors & $\begin{array}{c}\text { Number of } \\
\text { papers in } \\
\text { Scopus }\end{array}$ & $\begin{array}{c}\text { Number of } \\
\text { papers in } \\
\text { WoS } \\
\end{array}$ \\
\hline European Commission & 30 & 25 \\
\hline National Natural Science Foundation of China & 13 & 14 \\
\hline National Science Foundation & 10 & 3 \\
\hline $\begin{array}{l}\text { CoordenaÃß̃̃£o de AperfeiÃßoamento de Pessoal de } \\
\text { NÃvel Superior }\end{array}$ & 9 & 8 \\
\hline $\begin{array}{l}\text { Social Sciences and Humanities Research Council of } \\
\text { Canada }\end{array}$ & 8 & - \\
\hline United States Agency for International Development & 8 & 4 \\
\hline $\begin{array}{l}\text { Conselho Nacional de Desenvolvimento CientÃfico e } \\
\text { Tecnol } \tilde{A}^{3} \text { gico }\end{array}$ & 7 & 8 \\
\hline Economic and Social Research Council & 7 & 6 \\
\hline Japan Society for the Promotion of Science & 6 & 2 \\
\hline $\begin{array}{l}\text { DEUTSCHERAKADEMISCHERAUSTAUSCH } \\
\text { DIENST DAAD }\end{array}$ & 5 & 6 \\
\hline Canadian International Development Agency & 5 & - \\
\hline Department for International Development & 5 & 2 \\
\hline Ministry for Foreign Affairs & 5 & - \\
\hline National Research Foundation of Korea & 5 & 2 \\
\hline Universitas Indonesia & 5 & - \\
\hline
\end{tabular}

Sources: developed by the authors using Scopus Tools

It should be noted that the European Commission fully supports the dissemination of the concept of sustainable development, emphasizing that it is part of the European Commission's 10 priorities. In this regard, it runs an active information campaign and conducts numerous studies on this topic.

We use VOS viewer software for a more extensive bibliometric analysis of the studies of sustainable development in local communities. It makes it possible to create a map based on the analyzed data from scientometric databases. We explore the co-occurrence of keywords for a deeper understanding of the problems in the ranked works, (Fig. 3-4). 


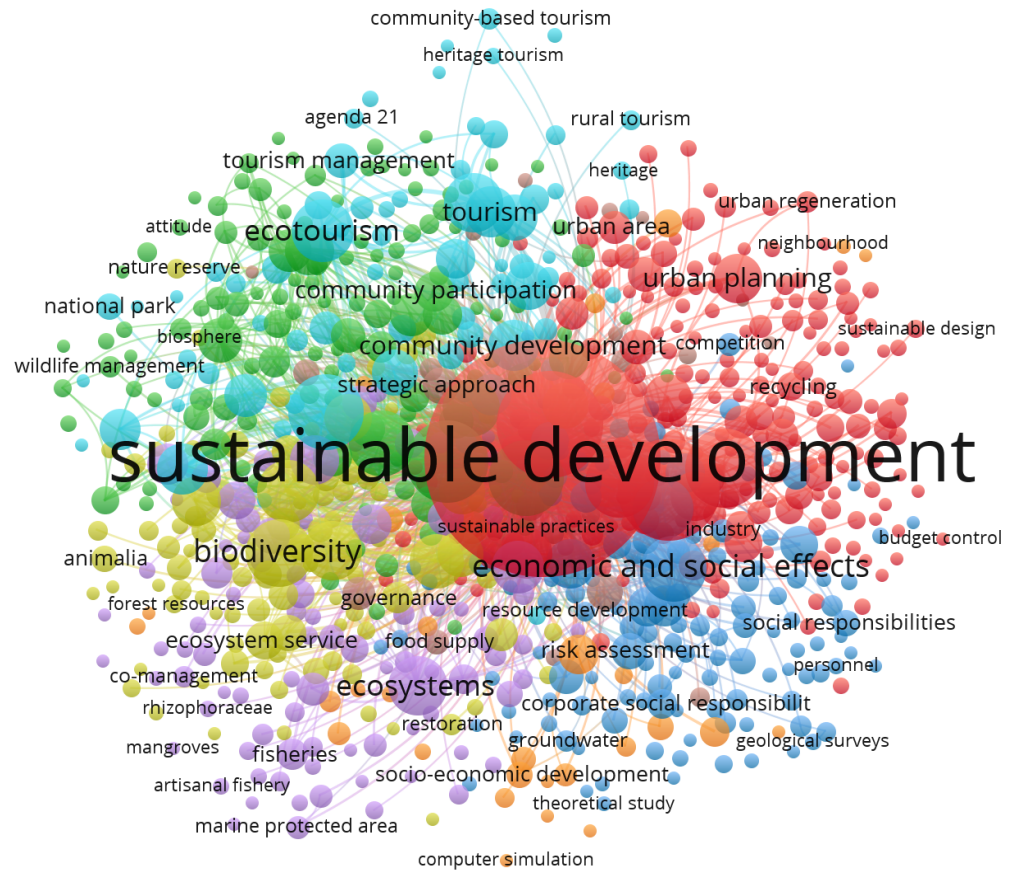

Fig. 3. The visualising map of papers on the sustainable development in local communities in Scopus database (Developed by the authors using VOS viewer)

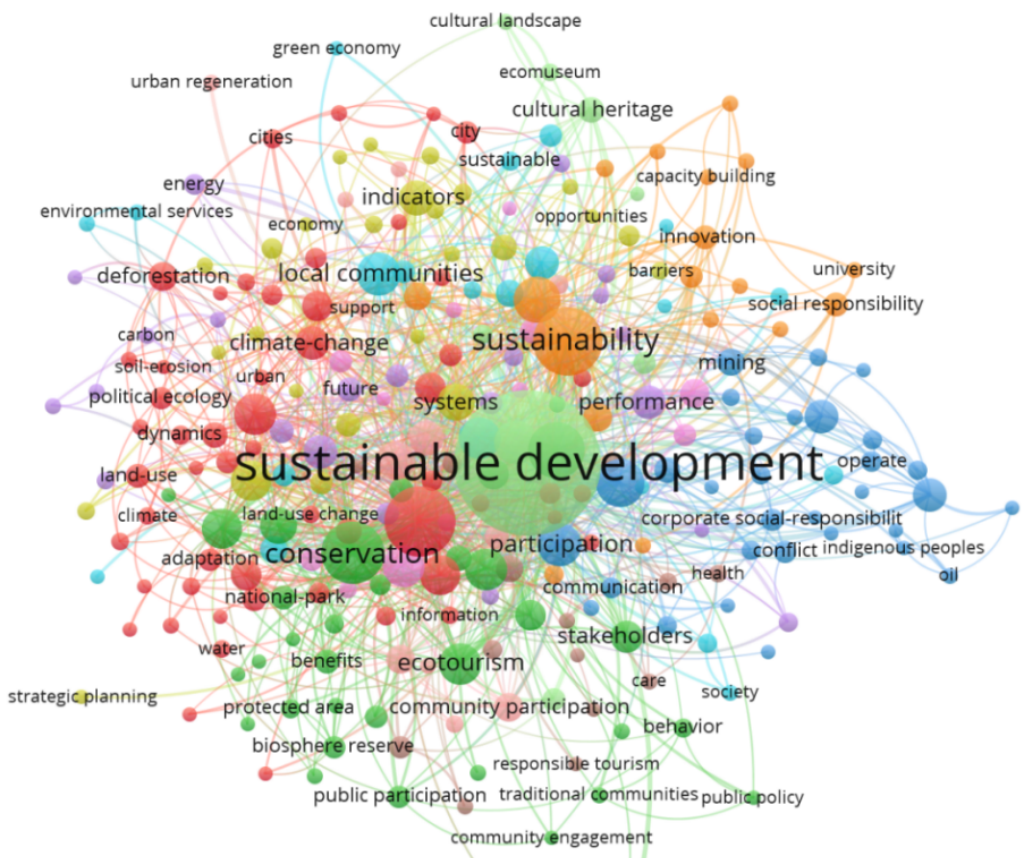

Fig. 4. The visualising map of papers on the sustainable development in local communities in WoS database (Developed by the authors using VOSviewer) 
As a result of the analysis of the Scopus database, 8 clusters were formed, which include 752 items. As we see in the figure, the red cluster plays the most important role. It is also the most numerous one including 189 items. The second-largest is the green cluster (126 works) followed by the blue cluster (123 works) and the yellow cluster (97 works). Regarding the WoS database, 11 clusters have been formed, which include 253 items and have a total of 3680 links. The largest cluster highlighted in red includes 54 works. The second-largest is the green cluster, which includes 34 works. The third-largest is the blue cluster with 31 works.

It should be noted that the item "local communities" in the Scopus database has 34992 links to all clusters, although it belongs to the first (red) one and is strongly linked to sustainable development. In addition, it has connections to works on environmental impact, strategic and urban planning, ecosystems, economic and social effects, participation, and so on (Fig. 5).

Regarding the WoS database, Item local communities has 63 links and also belongs to the field of scientific research in the recent years. The most relevant were the studies of local communities not only in the traditional context of local development but also in connection with corporate social responsibility, decentralization, rural development and environmental sustainability (Fig. 6).

In the context of our study it is interesting to consider the selection of works that explore sustainable development in the context of strategic planning. Due to the capabilities of VOS viewer, it was found that the item "strategic planning", which belongs to the third (blue) cluster according to the analysis of the Scopus database, has 253 links with a strength of 494; with regard to BOC, here "strategic planning" is also represented by a separate cluster and has 7 links to sustainable development. The most relevant topics include: sustainable development, local community, public policy, economic and social effects.

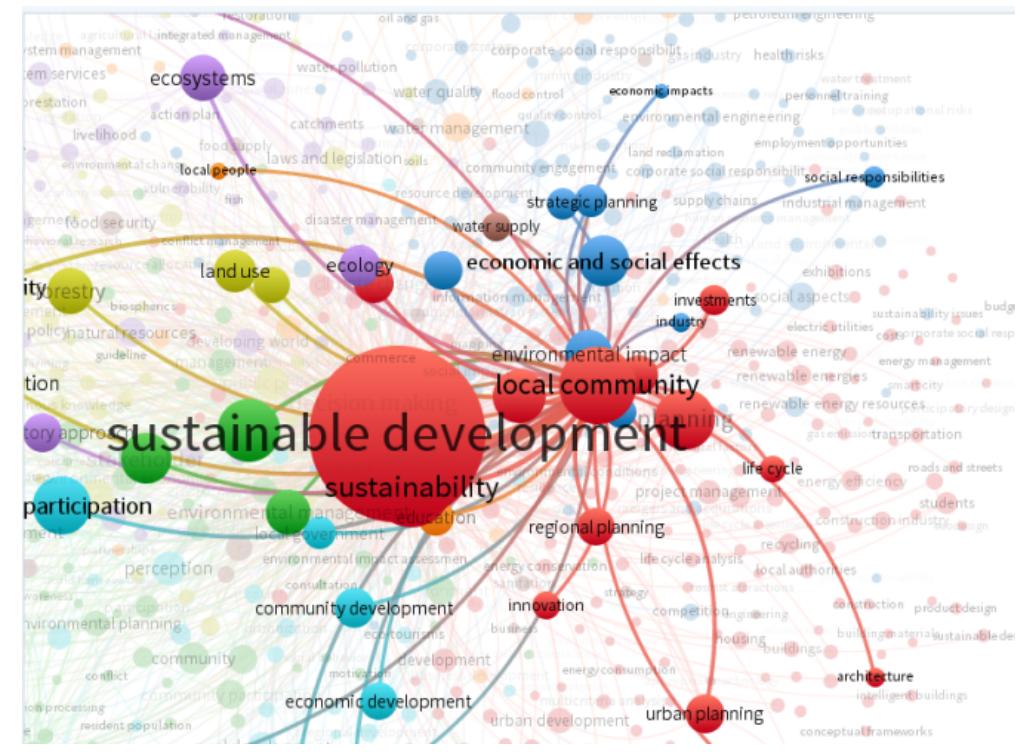

Fig. 5. Extract from the visualizing map of papers in relation to the links of local communities with other topics in the Scopus database (Developed by the authors using VOSviewer) 


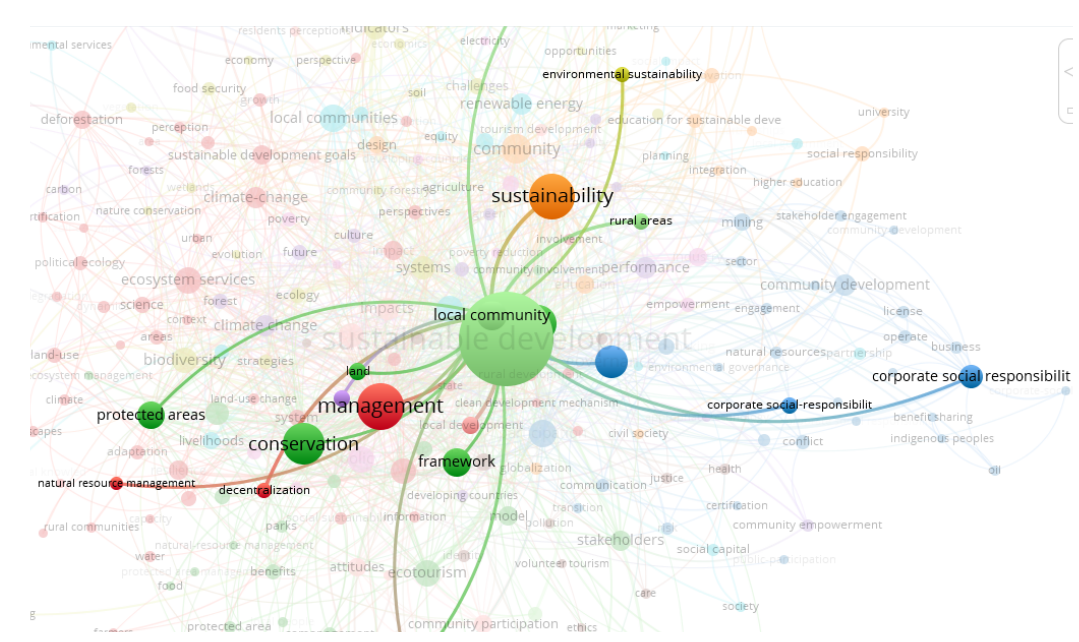

Fig. 6. Extract from the visualizing map of papers in relation to the links of local communities with other topics in the WoS database (Developed by the authors using VOS viewer)

\section{Conclusion}

The conducted bibliometric analysis made it possible to reveal the following positive tendencies concerning the development of scientific topic of the use of goals of sustainable development as a tool for strategic planning in territorial communities. The total number of works in the international scientific databases Scopus and WoS is growing, the geography of dissemination include mainly the United States, Britain and Australia, the most common subject areas are environmental and social sciences, the main sources of funding - the European Commission and the National Natural Science Foundation of China.

The results of bibliometric analysis in VOS viewer software allowed allocating main scientific clusters of connection of the theory of sustainable development with strategic planning of local communities. Thus, we obtained 8 clusters (in Scopus database) and 11 clusters (in WoS database) with the central term "sustainable development". It was proved the strong and reliable link between researches in field of sustainable development in local communities and strategic planning. The tendencies revealed in the academic literature have reinforced the belief that further research in this area is quite promising. 


\section{Funding}

This research was funded by the grant from the Ministry of Education and Science of Ukraine (Nos. g/r 0117U003935, 0120U102001).

\section{References}

1. O. Chygryn, Y. Petrushenko, A. Vysochyna, A. Vorontsova, Montenegrin journal of economics, Assessment of fiscal decentralization influence on social and economic development, 14 (4), 069-084 (2018).

2. T. Vasylieva, Y. Harust, N. Vynnychenko, A. Vysochyna, Marketing and Management of Innovations, Optimization of the financial decentralization level as an instrument for the country's innovative economic development regulation, 4, 382-391 (2018).

3. O. Tulai, Y. Petrushenko, J. Glova, I. Sydor, O. Ponomarenko, Investment Management and Financial Innovations, The impact of decentralization on the financial support of regional development, 16(4), 1-15 (2019).

4. Y. Petrushenko, N. Kostyuchenko, Y. Danko, Actual Problems of Economics, Conceptual framework of local development financing in UNDP projects in Ukraine, 159(9), 257-263 (2014).

5. H. Dkhili, Marketing and Management of Innovations, Environmental performance and institutions quality: evidence from developed and developing countries. 3, 333244 (2018).

6. E. Ivanová1, M. Kordoš Marketing and Management of Innovations, Competitiveness and innovation performance of regions in Slovak Republic, 1, 145-158 (2017).

7. O.Yu.Chygryn, V.S. Krasniak, Marketing and Management of Innovations, Theoretical and applied aspects of the development of environmental investment in Ukraine. 3, 226-234 (2015).

8. K. Kouassi, Financial Markets, Institutions and Risks, Public Spending and Economic Growth in Developing Countries: a Synthesis, 2(2), 22-30 (2018).

9. V. Pavlyk, Financial Markets, Institutions and Risks, Assessment of green investment impact on the energy efficiency gap of the national economy. 4(1), 117-123 (2020).

10. L. Hrytsenko, M. Petrushenko, K. Daher, SocioEconomic Challenges, The necessity of socio-ecological modification of two-tier economic model of secondary resources management in Ukraine, 1(1), 68-76 (2017).

11. J. Alam, B. Rashid, SocioEconomic Challenges, Influential Factors of Green Consciousness in Bangladesh: A Pragmatic Study on General Public in Dhaka City, 3(3), 98-107 (2019).

12. D. Bhowmik, SocioEconomic Challenges, Decoupling CO2 Emissions in Nordic countries: Panel Data Analysis, 3(2), 15-30 (2019).

13. T. Vasylyeva, S. Pryymenko, Actual Problems of Economics, Environmental economic assessment of energy resources in the context of ukraine's energy security 160(1), 252-260 (2014).

14. S. Lyeonov, T. Pimonenko, Y. Bila, D.Štreimikien, G. Mentel, Energies, Assessment of Green Investments' Impact on Sustainable Development: Linking Gross Domestic Product Per Capita, Greenhouse Gas Emissions and Renewable Energy,12(20), 3891 (2019). 
15. G. Mentel, T. Vasilyeva, Y. Samusevych, S. Pryymenko, International Journal of Environmental Technology and Management, Regional differentiation of electricity prices: Social-equitable approach, 21(5-6), 354-372 (2018).

16. O. Chygryn, T. Pimonenko, O. Luylyov, A. Goncharova, Journal of Environmental Management and Tourism, Green bonds like the incentive instrument for cleaner production at the government and corporate levels: Experience from EU to Ukraine, 9(7), 1443-1456 (2018).

17. T. Shevchenko, I. Koblianska, L. Saher, Journal of Environmental Management and Tourism, Development of biodegradable municipal waste separate collection system in Ukraine to fulfill the requirements of the European union directives, 7(3), 361-369 (2016).

18. H. Dave, Business Ethics and Leadership, An Inquiry on Social Issues - Part 1, 1(2), 78-87 (2017).

19. H. Dave, Business Ethics and Leadership, An Inquiry on Social Issues - Part 2, 1(3), 45-63 (2017).

20. J.G. Vargas-Hernandez, E.P. Orozco-Quijano, J. Virchez, SocioEconomic Challenges, Critical Analysis On Institutional Capital On Trade And Environmentally Sustainable Development Under NAFTA, 2(4), 21-31 (2018).

21. M. Kostel, D. Leus, A. Cebotarenco, A. Mokrushina, SocioEconomic Challenges, The Sustainable Development Goals for Eastern Partnership Countries: Impact of Institutions, 1(3), 79-90 (2017).

22. Y. Bilan, T. Vasilyeva, O. Lyulyov, T. Pimonenko, International Journal of Business and Society, EU vector of Ukraine development: Linking between macroeconomic stability and social progress 20(2), 433-450 (2019).

23. Y. Bilan, S.Lyeono, N.Stoyanet, A. Vysochyna, International Journal of Environmental Technology and Management, The impact of environmental determinants of sustainable agriculture on country food security, 21(5-6), 289-305 (2018).

24. O. Lyulyov, T. Pimonenko, N. Stoyanet, N. Letunovska, Research in World Economy, Sustainable development of agricultural sector: Democratic profile impact among developing countries, 10(4), 97-105 (2019).

25. N. Kostyuchenko, Y. Petrushenko, D. Smolennikov, Y. Danko, International Journal of Agricultural Resources, Governance and Ecology, Community-based approach to local development as a basis for sustainable agriculture: Experience from Ukraine, 11(2), 178-189 (2015).

26. S. Pryima, Y. Dayong, O. Anishenko, Y. Petrushenko, A. Vorontsova, Problems and Perspectives in Management, Lifelong learning progress monitoring as a tool for local development management, 16(3), 1-13 (2018).

27. I. Makarenko, N. Sirkovska, Business Ethics and Leadership, Transition to sustainability reporting: evidence from EU and Ukraine, (1)1, 16-24 (2017).

28. T.Vasilieva, S. Lieonov, I. Makarenko, N. Sirkovska, Marketing and Management of Innovations, Sustainability information disclosure as an instrument of marketing communication with stakeholders: markets, social and economic aspects, 4, 350-357 (2017).

29. I. Makarenko, D. Smolennikov,S. Makarenko, Espacios, Ukrainian national strategy for Corporate Social and Environmental Responsibility as a framework of responsible business conduct, 40(22) (2019). 
30. I. Serhii, G. Peresadko, O. Pidlisn, E. Kovalenko, Corporate Ownership and Control, Corporate social responsibility in marketing researches: Literature review, 11(4 Continued 5), 499-503 (2014).

31. L. Hrytsenko,T. Krasulya, Actual Problems of Economics, Risk management at realization of infrastructure projects under public-private partnership, 126(12), 85-90 (2011).

32. A. GrenÄ ÃkovÃ, Y. Bilan, Y. Samusevych, A. Vysochyna, Proceedings of the 33rd International Business Information Management Association Conference, IBIMA 2019: Education Excellence and Innovation Management through Vision, Drivers and inhibitors of entrepreneurship development in central and eastern European countries 2536-2547 (2019). 